\title{
Resilience of Bottomland Hardwood Stands Following Agricultural Use on the Santee Experimental Forest
}

\author{
Brooke J. Czwartacki, Carl C. Trettin \\ Center for Forested Wetland Research, Southern Research Station, USDA Forest Service, Cordesville, USA. \\ Email: bvjames@fs.fed.us
}

Received January $4^{\text {th }}, 2013$; revised February $16^{\text {th }}, 2013$; accepted February $26^{\text {th }}, 2013$

\begin{abstract}
Resilience is a key function that affects an ecosystem's ability to recover from disturbance. Understanding the extent to which forest communities recover after a long period of disturbance without direct intervention is important to provide context for considering ecosystem response to disturbance regimes. Species composition and structure were recorded on bottomland hardwood stands that were once inland and freshwater tidal rice fields. We sampled 17 old-field sites and 7 reference sites across three geomorphic settings. The old-field sites ranged from 30 to 120 years since agricultural abandonment. A total of 89 species were found across the old field sites and reference sample areas. Of that total, trees comprised 33 species, shrubs - 5 species, and vine/herbs/forbs - 51 species. Using field data, combined with stand inventory records, aerial photography (1936-2010), and high-resolution LiDAR imagery, we chronicled the evolution of the forest since the cessation of agriculture. Our findings demonstrate how Pinus taeda seeded directly after the rice fields went to fallow; and this conversion of bottomland swamp to rice to pine was a direct result of water management embankments constructed across the landscape to aid in crop irrigation. The remnant water management features may still alter flooding patterns thereby affecting development of Taxodium distichum and Nyssa aquatica in the old-fields. These results suggest, that over the 100+ years forest stands on the Santee Experimental Forest have developed to represent bottomland hardwoods characteristic of the southeastern United States coastal plain.
\end{abstract}

Keywords: Bottomland Hardwoods; Old-Field Succession; Rice Cultivation; Resilience; Santee Experimental Forest

\section{Introduction}

Resilience is a key function that affects an ecosystem's ability to recovery from disturbance. Degradation of resiliency may result in a regime shift with a concomitant loss or change in ecosystem services. Given concerns about how disturbance regimes or climate change may affect ecosystems, consideration of resiliency is particularly important. The basis for assessing resiliency is ideally the undisturbed system assessed in conjunction with varying levels of disturbance along spatial and temporal gradients [1]. However, for areas that have been highly disturbed, for example the coastal plain of the southeastern United States, which has been managed for over 300 years, the functionality of the pre-disturbance system is unknowable. Instead, reference systems are typically recognized as those without recent (e.g., >100 years) disturbances, despite the potential that their current condition may reflect a hysteretic artifact from the earlier disturbances [1,2]. Conversely, considering land use, environmental history, and the associated spatial and temporal changes in ecosystem composition and structure may provide a useful perspective on resiliency. Our objective is to utilize the Santee Experimental Forest to demonstrate the resilient nature of floodplain ecosystems of the lower Atlantic coastal plain; where the land has been used for agriculture, extraction of forest products, and active contemporary forest management, it has also been impacted by hurricanes. We suggest that important perspectives in resiliency are evident when current conditions are evaluated with respect to land use and disturbance history.

\subsection{Historical Development of the Lower Coastal Plain}

The lands comprising the SEF (Santee Experimental Forest), which are representative of the lower coastal plain, were characterized as a mosaic of pine-hardwood flatwoods and wetlands along the streams and ephemeral drainage ways. Commencing in the late seventeenth century, colonists began developing the landscape for the production of marine stores, crops and livestock [3-6]. The development began by cutting large trees and burning the underbrush and stumps, followed by the construction of water management structures for rice culti- 
vation. As the fields were developed, natural watercourses were channelized and diverted. Dams were constructed to impound areas as irrigation reservoirs. Those reservoirs served a dual purpose, to mitigate floodwaters during periods of excess precipitation, and retain irrigation water during times of drought $[3,4]$. Slight changes in topographic gradient allowed planters to establish reservoirs above the rice crops so that the crop could be flooded through gated trunks, and later drained off and diverted to canals [4]. Subsequently, in the early eighteenth century, plantations adjoining tidal creeks harnessed the freshwater tides as the basis for water management, and it became the preferred method of rice cultivation [3-6].

The agricultural use varied considerably between the 1700 's and 1800's, with lands used for cropping, livestock grazing, and fallow. By the turn of the 20th century, most of the plantation lands were sold to timber companies, and used as supply of raw materials for wood products. In 1905, a cooperative study by the USDA Bureau of Forestry focused on developing a timber management plan to maximize loblolly pine production [7]. The purpose of that report was to provide a basis for sustainable use of the forest. By the time of that report, it was noted that prior cultivated fields in the riparian zone were dominated by Pinus taeda.

\subsection{Forest Succession in Bottomlands of the Lower Coastal Plain}

Bottomland hardwood forests and swamp forests are the two predominant forest types on floodplains and riparian zones within the southeastern Atlantic coastal plain $[8,9]$. Bottomland hardwood forests are poorly drained areas commonly occupied by Quercus laurifolia, Quercus nigra, Quercus phellos, Quercus lyrata, Liquidambar styraciflua, Acer rubrum, Nyssa sylvatica, Fraxinus pennsylvanica, Ulmus americana, with Carpinus caroliniana, Ilex opaca, Cornus stricta, and Sabal minor in the understory [9]. Those species do not tolerate extended periods of saturated soils, and exist on natural levees and flats that have frequent periods of unsaturated conditions. Swamp forests exist in very poorly drained areas of the floodplain that may remain flooded for extended periods of the year with dominant swamp forest species Taxodium distichum and Nyssa aquatica $[8,9]$.

Bottomland hardwood forests take decades to reorganize into functional communities following disturbance regimes, and may not follow the typical paradigm of upland secondary succession because hydrologic regime is the primary determinant of vegetation dynamics $[10,11]$. However, bottomland forests represent some of the most productive ecosystems in the temperate region due to seasonal flooding patterns, and may reorganize quickly if seed sources are available $[8,10]$. Few studies have been conducted on secondary succession patterns following disturbance or cultivation on the southeastern coastal plain, and those available primarily focus on early stages of succession spanning 2 to 20 years [10-14]. There is a lack of information on forest succession in abandoned rice fields such as those found on the SEF, and throughout the lower coastal plain of South Carolina. The goal of this study was to characterize the succession of forest communities within bottomlands that had been formerly cultivated. Objectives addressed by study included (a) how long does it take for a bottomland hardwood forest to reach a steady state following a major landscape alteration, and (b) is the current bottomland hardwood forest similar to that which existed before agricultural conversion. Demonstrating resiliency in bottomland hardwood forests is fundamental in considering its response to perturbation regimes and climate change. Results of this work will enhance the understanding of bottomland hardwood site ecology and provide a basis for understanding resiliency in lower coastal plain bottomland forest sites.

\section{Materials and Methods}

\subsection{Study Sites}

The Santee Experimental Forest is located in the lower Atlantic coastal plain of South Carolina, (Figure 1) approximately $70 \mathrm{~km}$ northeast of Charleston, SC. The current forest is a mosaic of typical Atlantic Coastal Plain forest types categorized as an oak-gum-cypress forest. The predominant forest types are mixed hardwood-pine flatwoods and bottomland hardwoods floodplains [15]. Flatwoods lie at higher elevations than adjacent bottomland floodplains on natural levees, flats, and terraces with a mix of dry bottomland and upland species present [16]. Deep swamp species, Taxodium distichum and Nyssa aquatica frequent stream bottoms and known reservoir areas adjacent to the floodplain.

Elevation on the SEF ranges between 0 and 13 meters. Several low-order watersheds are present fed from seeps in the surrounding Francis Marion National Forest have been altered by channelization diversion, and impoundment $[2,3]$. The soils in the study area are of the Meggett series, and are described as fine, mixed, active, thermic Typic Albaqualfs that are poorly drained, nonacid, and clayey [17]. The climate of the region is subtropical with short, mild winters, and long, hot summers. The mean annual precipitation is approximately 1370 millimeters, and the long-term mean annual air temperature is $18.3^{\circ} \mathrm{C}$ [18].

\subsection{Sampling Framework}

The old-field cultivation areas were stratified into geo- 

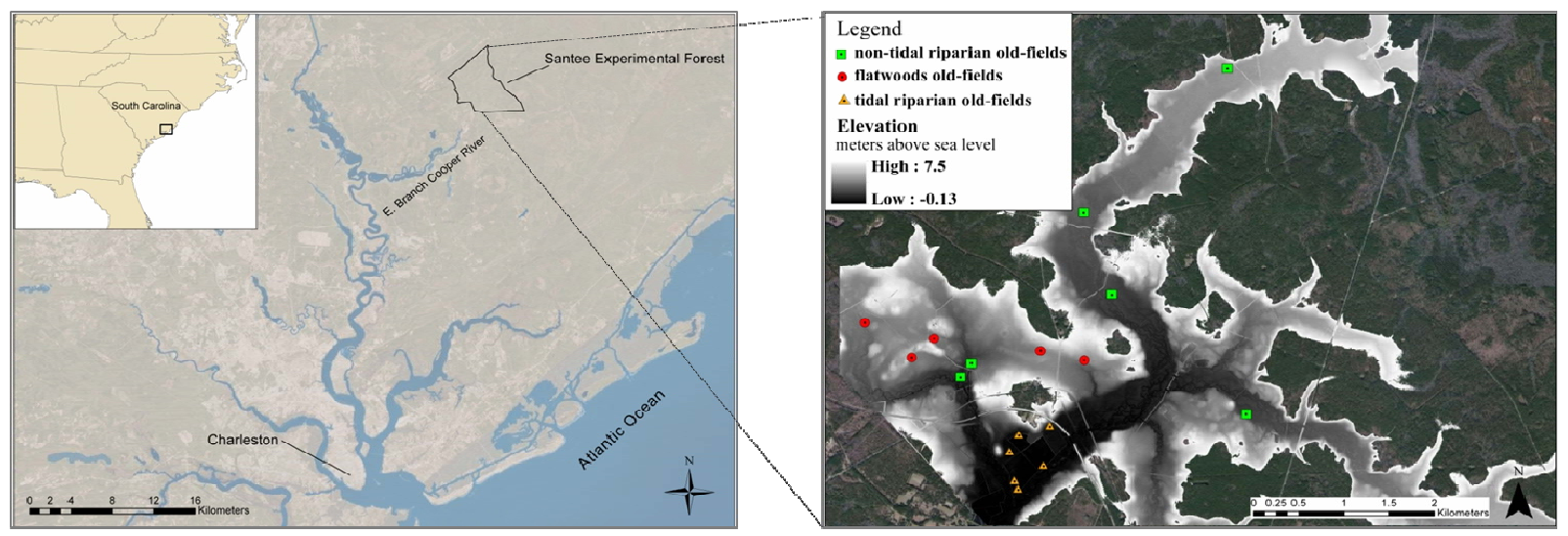

Figure 1. Map showing location of study area, and a DEM detailing site locations and elevations within the Santee Experimental Forest.

morphic settings defined by elevation and proximity to a watercourse. Elevation and the presence of dikes, banks, and canals were identified in a bare earth DEM that was derived from LiDAR. Locations of former rice fields were determined using plats of Limerick and Windsor Plantations, historical archives regarding land practices and ownership, forest notes, and the LiDAR imagery [19-21]. We identified three types of prior-cultivated field settings. The tidal riparian old-fields $(n=6)$ were located between $0.37 \mathrm{~m}$ and $1.63 \mathrm{~m}$. The non-tidal old fields $(\mathrm{n}=11)$ were located between $1.9 \mathrm{~m}$ and $4.9 \mathrm{~m}$. The non-tidal old-fields were further divided into non-tidal riparian and flatwoods old-field sites. Non-tidal riparian old-fields $(\mathrm{n}=6)$ were located within the riparian zone of creek bottoms directly adjacent to the creek or reservoir that provided irrigation. The flatwoods oldfields $(n=5)$ were located in the upland areas where water had been diverted across the landscape for irrigation. We also chose seven sites to serve as reference sites to compare the forest composition in areas that appeared never to be in cultivation. Vegetation was separated into three strata: overstory trees, understory shrubs and saplings, and a ground cover layer. Overstory vegetation included all woody vegetation measuring $\geq 2.5 \mathrm{~cm}$ dbh (diameter at breast height, 1.4 meters). Understory vegetation consisted of saplings and shrubs $\geq 30 \mathrm{~cm}$ in height, and $<2.5 \mathrm{~cm}$ dbh. The ground cover component included all herbaceous species, vines, and woody vegetation $<30$ $\mathrm{cm}$ tall.

Two plots $\left(100-\mathrm{m}^{2}\right)$ were measured at every old-field or reference site. Understory and ground cover plots were nested within the overstory plot. Understory plots measured $16-\mathrm{m}^{2}$, where the number of stems (one stem $=$ one individual) for each species was recorded. A $1-\mathrm{m}^{2}$ quadrat was thrown in two random locations from the midpoint of each overstory plot. The density of each species was estimated by assigning percent cover to plants crossing the plane of the $1-\mathrm{m}^{2}$ quadrat [22]. Tree diame- ter was measured to the nearest millimeter.

\subsection{Data Analysis}

In the overstory, the total number of species, total number of individuals was recorded, and basal area per hectare (Equation (1)) was computed. Species dominance values were standardized to hectares using a scaling factor which depended on the total area sampled.

$$
\text { B.A. } \mathbf{m}^{2} \cdot \mathbf{h a}^{-1}=\frac{\boldsymbol{\pi} \times\left(\frac{\mathbf{D B H}}{2}\right)^{2}}{10^{4}} \times(\text { scaling factor })
$$

Importance values were calculated to describe relative dominance of overstory species within old fields versus reference sites. Importance value (IV) was derived from the sum of relative dominance, relative density, and relative frequency, and were calculated as follows:

$$
\text { Relative dominance }=\frac{\text { total B.A. for a species }}{\text { total B.A. for all species }} \times 100
$$

Relative density $=\frac{\# \text { of individuals of a species }}{\text { total number of individuals }} \times 100$

$$
\text { Relative frequency }=\frac{\text { frequency of a species }}{\text { sum frequencies of all species }} \times 100
$$

Understory density was calculated by multiplying the total number of an individual species recorded by a scaling factor to show density per hectare. Ground cover was calculated as the mean percent ground cover in each geomorphic setting, (Equation (2)) and was derived by summing the percent cover for each species found divided by the total number of throws.

$$
\begin{aligned}
& \text { Mean } \% \text { cover } \\
& =\frac{((\% \text { cover } \mathbf{t} 1)+(\% \text { cover } \mathbf{t} 2)+(\% \text { cover } \mathbf{t} 3) \cdots)}{\text { total number of throws }} \\
& \times 100
\end{aligned}
$$




\section{Results}

A total of 89 species were found across all old-field and reference sites. Of that total, trees comprised 33 species, shrubs - 5 species, and vine/ herbs/ forbs - 51 species. Species richness varied between geomorphic settings, and old-field sites versus reference sites. Non-tidal riparian sites had the highest number of species totaling 61 species; followed by the tidal riparian and flatwoods, 58 and 52 species, respectively.

\subsection{Tidal Riparian}

The elevation of the tidal riparian old-field sites were found directly above the mean high-tide level. When the forestland was converted into agriculture, earthen dikes were constructed to prevent the highest tides from entering the rice fields [5]. Adjoining trunks fitted with tide gates allowed planters to regulate flooding. The presence of these embankments still restricts daily inundation, but a large portion is seasonally flooded for waterfowl management. All of the old-field sites were very flat and surrounded by a ditch that historically provided irrigation. The old-fields had been let go in stages, and were in varying stages of forest succession, spanning 30 to 100 years. Overall stand basal area was slightly higher in the old-fields versus the reference sites (Table 1). The most important trees in the old-fields were A. rubrum, Triadica sebifera, Myrica cerifera, and L. styraciflua, compared to Q. laurifolia, A. rubrum, and Quercus pagoda in the reference site. There was greater diversity and stems per hectare in the old fields shrub strata compared to the reference site, (Table 2) with A. rubrum saplings appearing most frequently in old field sites, followed by $M$. cerifera. A. rubrum did not appear in the reference site, and was dominated by $M$. cerifera. In the ground component, total mean percent ground cover was similar at both old-fields and the reference sites (Table 3). While old-field sites had higher species richness, each species represented low cover.

\subsection{Non-Tidal Riparian}

The non-tidal riparian old-field sites were generally wet with active small stream channels running through them, and showed evidence of seasonal flooding. Each was flat with little to no undulation or variation in the land surface, bordered by a perimeter of raised banks with ditching on both the interior and exterior sides of the bank, and directly adjacent to streams or breached reservoir areas. We estimated that the old-fields had been out of cultivation between 80 - 120 years. All of the reference sites were geographically similar to the old-fields, but lacked visible earthen levees and exhibited more microtopography than abandoned field sites.
Table 1. Overstory basal area $\left(\mathrm{m}^{2} \cdot \mathrm{ha}^{-1}\right)$ and species importance value (IV) within tidal riparian old-fields and the reference site.

\begin{tabular}{|c|c|c|c|c|}
\hline \multirow[t]{2}{*}{ Species } & \multicolumn{2}{|c|}{ Old-field } & \multicolumn{2}{|c|}{ Reference } \\
\hline & $\begin{array}{l}\text { B.A. } \\
\mathrm{m}^{2} \cdot \mathrm{ha}^{-1}\end{array}$ & IV & $\begin{array}{c}\text { B.A. } \\
\mathrm{m}^{2} \cdot \mathrm{ha}^{-1}\end{array}$ & IV \\
\hline Acer rubrum & 9.4 & 61.6 & 2.9 & 42.5 \\
\hline Triadica sebifera & 2.3 & 28.6 & & \\
\hline Myrica cerifera & 0.2 & 14.4 & 0.1 & 20.0 \\
\hline Liquidambar styraciflua & 1.0 & 14.1 & & \\
\hline Fraxinus pennsylvanica & 0.8 & 11.1 & & \\
\hline Salix nigra & 2.4 & 10.9 & & \\
\hline Quercus laurifolia & 0.6 & 10.5 & 19.5 & 124.6 \\
\hline Pinus taeda & 5.2 & 10.4 & & \\
\hline Diospyros virginiana & 0.6 & 9.6 & & \\
\hline Quercus pagoda & 9.2 & 7.5 & 6.9 & 41.6 \\
\hline Nyssa sylvatica & 2.3 & 7.5 & 0.8 & 24.9 \\
\hline Juniperus virginiana & 0.03 & 4.0 & & \\
\hline Celtis laevigata & 1.1 & 3.2 & & \\
\hline Fagus grandifolia & 0.03 & 3.2 & & \\
\hline Cornus sp. & 0.01 & 3.2 & & \\
\hline Ulmus alata & & & 0.2 & 17.6 \\
\hline Persea borbonia & & & 1.2 & 28.8 \\
\hline Total & 35.2 & & 31.6 & \\
\hline
\end{tabular}

Table 2. Number of stems per hectare in shrub strata, within tidal riparian old-fields and the reference site.

\begin{tabular}{lcc}
\hline Species & $\begin{array}{c}\text { Old-field } \\
\text { stems ha }^{-1}\end{array}$ & $\begin{array}{c}\text { Reference } \\
\text { stems ha }^{-1}\end{array}$ \\
\hline Acer rubrum & 2291.5 & \\
Myrica cerifera & 1927 & 5000 \\
Fraxinus pennsylvanica & 833.3 & \\
Callicarpa americana & 416.6 & \\
Vaccinium spp. & 416.6 & \\
Diospyros virginiana & 468.7 & \\
Ilex decidua & 208.3 & 312.5 \\
Rosa multiflora & 52.1 & \\
Triadica sebifera & 208.3 & \\
Liquidambar styraciflua & 52.1 & \\
Morus rubra & 52.1 & \\
Quercus laurifolia & 625 & \\
Sabal minor & & 312.5 \\
Pinus taeda & & 312.5 \\
Viburnum dentatum & & 6250 \\
Total & 7551.6 & \\
\hline
\end{tabular}


Table 3. Mean percent ground cover in tidal riparian oldfields and the reference site.

\begin{tabular}{|c|c|c|}
\hline Species & Old-field & Reference \\
\hline \multicolumn{3}{|l|}{ Percent cover } \\
\hline Ampelopsis arborea & 11.9 & 0.5 \\
\hline Parthenocissus quinquefolia & 10.9 & 4.3 \\
\hline Lemna minor & 9.6 & \\
\hline Cyperaceae & 7.8 & \\
\hline Panicum spp. & 6.4 & 1.8 \\
\hline Acer rubrum & 6.3 & 3.8 \\
\hline Scirpus validus & 4.7 & \\
\hline Alternanthera philoxeroides & 3.5 & \\
\hline Toxicodendron radicans & 3.4 & 1.3 \\
\hline Polygonum laurifolium & 2.3 & \\
\hline Lonicera japonica & 2.1 & \\
\hline Vitis rotundifolia & 1.8 & 0.5 \\
\hline Athyrium asplenioides & 1.5 & \\
\hline Ludwigia palustris & 1.5 & \\
\hline Pinus taeda & 1.5 & \\
\hline Peltandra virginica & 1.4 & \\
\hline Fraxinus pennsylvanica & 1.3 & \\
\hline Hydrocotyle umbellata & 1.3 & 1.3 \\
\hline Smilax spp. & 1.3 & 10.0 \\
\hline Asteraceae & 1.0 & \\
\hline Campsis radicans & 1.0 & \\
\hline Gelsemium sempervirens & 1.0 & \\
\hline Myrica cerifera & 1.0 & 11.3 \\
\hline Rubus hispidus & 1.0 & 10.0 \\
\hline Berchemia scandens & 0.9 & 5.0 \\
\hline Ambrosia artemisiifolia & 0.8 & \\
\hline Diospyros virginiana & 0.7 & \\
\hline Ilex ораса & 0.5 & \\
\hline Triadica sebifera & 0.5 & \\
\hline Ilex decidua & 0.2 & \\
\hline Polygonum densiflorum & 0.2 & \\
\hline Wisteria sinensis & 0.2 & \\
\hline Aster spp. & 0.2 & \\
\hline Albizia julibrissin & 0.1 & \\
\hline Boehmeria cylindrica & 0.1 & \\
\hline Celtis laevigata & 0.1 & \\
\hline Desmodium obtusum & 0.1 & \\
\hline Liquidambar styraciflua & 0.1 & \\
\hline Solanum carolinense & 0.1 & \\
\hline Ulmus alata & 0.1 & \\
\hline unknown forb & 0.1 & \\
\hline Sabal minor & & 18.0 \\
\hline Quercus laurifolia & & 11.8 \\
\hline Mitchella repens & & 10.0 \\
\hline Viola spp. & & 2.5 \\
\hline Rosa palustris & & 2.5 \\
\hline Total & $90 \%$ & $94 \%$ \\
\hline
\end{tabular}

Only one reference site was measured for the shrub and ground strata. In the overstory, there was little difference in total average stand basal area between the old-fields and reference sites. The most important overstory species in the old-field sites were Q. laurifolia, C. caroliniana, and A. rubrum (Table 4). In the reference sites, the most important overstory species were $Q$. laurifolia, L. styraciflua, and C. caroliniana. Deep swamp species, $T$. distichum and $N$. aquatica were identified, but not with high importance in old-fields or reference sites. In the shrub strata, (Table 5) Q. laurifolia had the highest density out of the 13 species identified, and in the reference site, only Ilex decidua was recorded, but it was noted that the shrub layer was largely absent. In the ground component, total mean percent ground cover was $67 \%$ in the old fields compared to $92 \%$ in the reference site (Table 6). Species richness in the oldfields was greater than the reference, but most species

Table 4. Overstory basal area $\left(\mathrm{m}^{2} \cdot \mathrm{ha}^{-1}\right)$ and importance value (IV) in non-tidal riparian old-fields and reference sites $(n=4)$.

\begin{tabular}{|c|c|c|c|c|}
\hline \multirow[t]{2}{*}{ Species } & \multicolumn{2}{|c|}{ Old-field } & \multicolumn{2}{|c|}{ Reference } \\
\hline & $\begin{array}{l}\text { B.A. } \\
\mathrm{m}^{2} \cdot \mathrm{ha}^{-1}\end{array}$ & IV & $\begin{array}{c}\text { B.A. } \\
\mathrm{m}^{2} \cdot \mathrm{ha}^{-1}\end{array}$ & IV \\
\hline Quercus laurifolia & 7.9 & 59.9 & 12.2 & 87.3 \\
\hline Carpinus caroliniana & 1.9 & 29.6 & 1.6 & 26.6 \\
\hline Acer rubrum & 2.6 & 25.6 & 3.6 & 25.0 \\
\hline Quercus pagoda & 5.1 & 25.5 & & \\
\hline Cornus sp. & 0.6 & 23.0 & & \\
\hline Ulmus americana & 2.3 & 19.4 & 2.1 & 20.6 \\
\hline Fraxinus pennsylvanica & 1.9 & 18.7 & 3.0 & 19.3 \\
\hline Liquidambar styraciflua & 1.6 & 17.7 & 4.3 & 28.1 \\
\hline Nyssa sylvatica & 1.0 & 17.0 & 1.0 & 17.0 \\
\hline Ulmus alata & 1.7 & 15.7 & 0.4 & 5.8 \\
\hline Ilex decidua & 0.2 & 7.3 & 0.3 & 10.3 \\
\hline Quercus michauxii & 0.4 & 6.6 & & \\
\hline Nyssa aquatica & 0.4 & 6.1 & & \\
\hline Acer negundo & 0.2 & 6.1 & & \\
\hline Ilex ораса & 0.4 & 5.5 & 0.2 & 11.5 \\
\hline Celtis laevigata & 0.1 & 4.5 & 0.2 & 4.5 \\
\hline Pinus taeda & 0.3 & 3.0 & & \\
\hline Taxodium distichum & 0.2 & 2.8 & 0.6 & 9.6 \\
\hline Morus rubra & 0.1 & 2.3 & & \\
\hline Carya cordiformis & 0.03 & 2.2 & & \\
\hline Crataegus flava & 0.01 & 2.1 & & \\
\hline Quercus lyrata & & & 0.5 & 4.9 \\
\hline Carya sp. & & & 0.4 & 4.6 \\
\hline Carya aquatica & & & 0.03 & 3.4 \\
\hline Total & 28.9 & & 30.4 & \\
\hline
\end{tabular}


Table 5. Number of stems per hectare of shrub strata within non-tidal riparian old-fields and the reference site.

\begin{tabular}{lcc}
\hline Species & $\begin{array}{c}\text { Old-field } \\
\text { stems ha }\end{array}$ & $\begin{array}{c}\text { Reference } \\
\text { stems ha }^{-1}\end{array}$ \\
\hline Quercus laurifolia & 1093.7 & \\
Carpinus caroliniana & 312.5 \\
Fraxinus pennsylvanica & 312.5 \\
Fagus grandifolia & 260.4 \\
Ilex opaca & 208.3 \\
Nyssa sylvatica & 208.3 \\
Acer negundo & 104.2 \\
Cornus sp. & 52.1 \\
Diospyros virginiana & 52.1 \\
Ilex decidua & 52.1 \\
Quercus marilandica & 52.1 \\
Sabal minor & 52.1 \\
Taxodium distichum & 52.1 \\
Total & 2812.5 \\
\hline
\end{tabular}

only contributed a small percent cover. Cyperaceae covered $22.5 \%$ of the old-field sites and was absent at the reference site.

\subsection{Flatwoods}

The flatwoods stands were comprised of mixed pine and hardwood species, moist, but drier than adjacent bottomlands with no evidence of seasonal flooding. We estimated that the flatwoods old-field sites had been out of cultivation for 80 to 120 years.

The total average stand basal area was higher in the reference site due to the frequency of and diameter of several P. taeda (Table 7). The most important overstory species in the old fields were C. caroliniana, Q. pagoda, and L. styraciflua. In the reference site, Q. pagoda and $N$. sylvatica were co-dominants with $P$. taeda. The flatwoods shrub layer (Table 8) was dominated by C. caroliniana and other overstory species, compared to the sparse understory of the reference site with $M$. cerifera dominant, occurring with I. opaca and Q. nigra. In the old-fields of the ground component (Table 9) were dense and diverse and dominated by Cyperaceae (19\%). We did not observe the same in the reference site, where the forest floor was thick with pine needles and few vegetative species contributed to the overall ground cover.

\section{Discussion}

The secondary forest communities occurring on old rice
Table 6. Mean percent ground cover in non-tidal riparian old-fields and the reference site.

\begin{tabular}{|c|c|c|}
\hline Species & Old-field & Reference \\
\hline \multicolumn{3}{|l|}{ Percent cover } \\
\hline Cyperaceae & 22.5 & \\
\hline Smilax spp. & 6.0 & 8.8 \\
\hline Toxicodendron radicans & 4.8 & 1.8 \\
\hline Panicum spp. & 3.0 & 1.8 \\
\hline Mitchella repens & 2.7 & 10.0 \\
\hline Parthenocissus quinquefolia & 2.5 & 4.3 \\
\hline Polygonum virginianum & 1.9 & \\
\hline Vitis rotundifolia & 1.8 & 0.5 \\
\hline Viola spp. & 1.5 & 3.8 \\
\hline Ampelopsis arborea & 1.5 & 0.5 \\
\hline Ulmus alata & 1.3 & \\
\hline Fagus grandifolia & 1.3 & \\
\hline Liquidambar styraciflua & 1.2 & \\
\hline Lonicera japonica & 1.2 & \\
\hline Actaea racemosa & 1.1 & \\
\hline Ulmus americana & 1.0 & \\
\hline Berchemia scandens & 1.0 & 0.5 \\
\hline unknown forb & 0.9 & \\
\hline Campsis radicans & 0.9 & \\
\hline Fraxinus pennsylvanica & 0.8 & \\
\hline Rubus hispidus & 0.8 & 10.0 \\
\hline Sabal minor & 0.8 & 18.0 \\
\hline Quercus laurifolia & 0.8 & 11.8 \\
\hline Triadica sebifera & 0.7 & \\
\hline Asteraceae & 0.6 & \\
\hline Rosa palustris & 0.6 & 2.5 \\
\hline Bignonia capreolata & 0.5 & \\
\hline Galium triflorum & 0.5 & \\
\hline Rosa multiflora & 0.4 & \\
\hline Tillandsia usneoides & 0.4 & \\
\hline Acer rubrum & 0.4 & 3.8 \\
\hline Gelsemium sempervirens & 0.3 & \\
\hline Ilex decidua & 0.3 & \\
\hline Euonymus americana & 0.2 & \\
\hline Trachelospermum difforme & 0.2 & \\
\hline Carpinus caroliniana & 0.1 & \\
\hline Ambrosia artemisiifolia & 0.1 & \\
\hline Asplenium platyneuron & 0.1 & \\
\hline Cornus sp. & 0.1 & \\
\hline Helenium autumnale & 0.1 & \\
\hline Hypericum perforatum & 0.1 & \\
\hline Pinus taeda & 0.1 & \\
\hline Sphagnum spp. & 0.1 & \\
\hline Vaccinium spp. & 0.1 & \\
\hline Myrica cerifera & & 11.3 \\
\hline Callicarpa americana & & 2.5 \\
\hline Total & $67 \%$ & $92 \%$ \\
\hline
\end{tabular}


Table 7. Overstory basal area $\left(\mathrm{m}^{2} \cdot \mathrm{ha}^{-1}\right)$ and species importance value (IV) in flatwoods old-fields and the reference site.

\begin{tabular}{|c|c|c|c|c|}
\hline Species & Old-fiel & & Referer & \\
\hline & $\begin{array}{c}\text { B.A. } \\
\mathrm{m}^{2} \cdot \mathrm{ha}^{-1}\end{array}$ & IV & $\begin{array}{c}\text { B.A. } \\
\mathrm{m}^{2} \cdot \mathrm{ha}^{-1}\end{array}$ & IV \\
\hline Carpinus caroliniana & 5.0 & 53.5 & & \\
\hline Quercus pagoda & 9.4 & 49.6 & 7.9 & 44.2 \\
\hline Liquidambar styraciflua & 6.1 & 36.7 & 2.8 & \\
\hline Acer rubrum & 1.5 & 22.3 & & \\
\hline Ulmus alata & 1.1 & 22.1 & & \\
\hline Quercus laurifolia & 2.4 & 14.3 & & \\
\hline Fraxinus pennsylvanica & 1.3 & 14.1 & & \\
\hline Pinus taeda & 1.4 & 11.8 & 28.0 & 122.9 \\
\hline Ulmus Americana & 0.3 & 10.6 & & \\
\hline Cornus sp. & 0.3 & 10.6 & & \\
\hline Nyssa sylvatica & 0.2 & 9.8 & 4.4 & 36.4 \\
\hline Quercus nigra & 0.3 & 8.9 & 0.1 & 35.1 \\
\hline Myrica cerifera & 0.03 & 6.5 & & \\
\hline Celtis laevigata & 0.2 & 6.1 & & \\
\hline Quercus michauxii & 0.5 & 4.5 & & \\
\hline Quercus virginiana & 0.4 & 4.0 & & \\
\hline Fagus grandifolia & 0.1 & 3.4 & 1.1 & 19.2 \\
\hline Triadica sebifera & 0.1 & 2.9 & & \\
\hline Acer negundo & 0.1 & 2.9 & & \\
\hline Viburnum dentatum & 0.03 & 2.8 & & \\
\hline Carya cordiformis & 0.02 & 2.8 & & \\
\hline Ilex ораса & & & 0.6 & 22.8 \\
\hline Total & 30.8 & & 44.9 & \\
\hline
\end{tabular}

Table 8. Number of stems per hectare in shrub strata within flatwoods old-fields and the reference site.

\begin{tabular}{lcc}
\hline Species & $\begin{array}{c}\text { Old-field } \\
\text { stems ha }\end{array}$ & $\begin{array}{c}\text { Reference } \\
\text { stems ha }^{-1}\end{array}$ \\
\hline Carpinus caroliniana & 1000 & \\
Ulmus alata & 437.5 & \\
Fraxinus pennsylvanica & 312.5 & \\
Quercus nigra & 250 & 312.5 \\
Cornus sp. & 187.5 & \\
Ilex opaca & 187.5 & 312.5 \\
Liquidambar styraciflua & 187.5 & \\
Vaccinium spp. & 187.5 & \\
Viburnum dentatum & 187.5 & \\
Myrica cerifera & 125 & 1250 \\
Nyssa sylvatica & 125 & \\
Quercus pagoda & 125 & \\
Quercus laurifolia & 62.5 & \\
Total & 3375 & \\
\hline
\end{tabular}

Table 9. Mean percent ground cover of flatwoods old-fields and reference site.

\begin{tabular}{|c|c|c|}
\hline Species & Old-field & Reference \\
\hline \multicolumn{3}{|l|}{ Percent cover } \\
\hline Cyperaceae & 19.0 & 1.8 \\
\hline Mitchella repens & 15.3 & 12.5 \\
\hline Panicum spp. & 10.9 & 6.3 \\
\hline Smilax spp. & 10.4 & 1.3 \\
\hline Parthenocissus quinquefolia & 7.8 & 0.5 \\
\hline Carpinus caroliniana & 3.9 & \\
\hline Myrica cerifera & 3.8 & \\
\hline Ampelopsis arborea & 3.0 & \\
\hline Bignonia capreolata & 2.8 & \\
\hline Toxicodendron radicans & 2.8 & \\
\hline Vitis rotundifolia & 2.3 & 28.0 \\
\hline Rubus hispidus & 2.1 & \\
\hline Taraxacum sp. & 2.0 & \\
\hline Epilobium angustifolium & 1.8 & \\
\hline Berchemia scandens & 1.2 & 0.5 \\
\hline Campsis radicans & 1.2 & \\
\hline Ulmus alata & 1.1 & 1.3 \\
\hline Quercus pagoda & 0.8 & \\
\hline Rosa palustris & 0.8 & \\
\hline Sabal minor & 0.8 & \\
\hline Lonicera japonica & 0.5 & 1.3 \\
\hline Persea borbonia & 0.5 & \\
\hline Acer rubrum & 0.4 & \\
\hline Duchesnea indica & 0.3 & \\
\hline Viola spp. & 0.3 & \\
\hline Quercus nigra & 0.3 & 0.5 \\
\hline Sphagnum spp. & 0.3 & \\
\hline Asarum canadense & 0.2 & \\
\hline Liquidambar styraciflua & 0.2 & 3.0 \\
\hline Echinacea purpurea & 0.1 & \\
\hline Galium triflorum & 0.1 & \\
\hline Gelsemium sempervirens & 0.1 & \\
\hline Lonicera sempervirens & 0.1 & \\
\hline Quercus laurifolia & 0.1 & \\
\hline Quercus spp. & 0.1 & \\
\hline Scutellaria lateriflora & 0.1 & \\
\hline Vaccinium spp. & 0.1 & \\
\hline Euonymus americana & & 1.3 \\
\hline Nyssa sylvatica & & 1.0 \\
\hline Pinus taeda & & 0.5 \\
\hline Triadica sebifera & & 0.5 \\
\hline Total & $97 \%$ & $60 \%$ \\
\hline
\end{tabular}


fields within the SEF are similar in composition across all strata and geomorphic settings and resemble typical bottomlands of the region $[9,16]$. Our data suggest that secondary succession to bottomland can happen relatively quickly, where pioneer species co-exist, but are eventually out competed by hardier shade tolerant species. For example, the tidal riparian old-fields were the most recently forested in our study, and while there was high importance of early pioneer species $T$. sebifera, the combined presence of A. rubrum and Q. laurifolia and other commonly identified and important overstory species seen in all geomorphic old-field and reference sites in this study suggest that these bottomlands do reorganize quickly provided the seed source is available.

While we observed significant overlap between sites, discrete differences in overall species composition between individual strata indicate that hydrology played a role in species distribution and composition. The presence of remnant embankments has hydrologically isolated the old-fields within the floodplain, and may provide some reasoning as to the low importance of deep swamp species. When the landscape was altered 300 years ago, it is probable that large amounts of substrate were removed to achieve an even grading for rice cultivation [3]. During this excavation, existing seed banks of T. distichum were likely removed and successive communities have not been re-established due to the flooding patterns across the floodplain. In a related study on old rice field succession, $T$. distichum communities returned in a 132-year-old abandoned rice field on the Waccamaw River, SC [14]. It was estimated that $90 \mathrm{~cm}$ of soil was removed, but $T$. distichum re-established through hydrochory, the dispersal of seeds by water. However, hydrochory may not be a functional mechanism here on the SEF. The Waccamaw River is a large river system compared to the low order, ephemeral drainages on the SEF that do not have significant flows throughout the year to allow for complete seed dispersal through water. Further, the success of $T$. distichum depends on the viability of its seeds, which require alternating periods of wet and dry for success, the old-fields on the SEF are not cycling through wet and dry periods needed for establishment. Dispersal of seeds by wind and animals are the likely mechanisms affecting colonization on these sites [11,23].

In secondary succession, environmental gradients influence species composition and distribution, therefore, it is important to include the hydrologic gradient associated with microtopography, or the lack thereof in old-field succession $[11,12]$. Our tidal and non-tidal riparian reference sites had visible microtopography and slight variations in stand composition when compared to the old-fields. The largest differences were seen in the ground component. We did however; observe an abundance sedge species in the old-field sites. We attribute this large presence to seasonal flooding and shade. In a related study, flooding patterns from low surface topography were found to alter herbaceous species, where wetland grasses cover fields from continued environmental stress [14]. Our data supported this finding, as we found sedges covering an average of $23 \%$ of the forest floor in the non-tidal riparian old-fields, $19 \%$ of the flat woods old-fields, and $8 \%$ of tidal sites. This was not an observation in the reference sites that exhibited hummock and hollow topography. Few species can grow in waterlogged soils of the hollows. The reference sites were generally sparse with a mix of small trees, shrubs, and herbaceous species occupying the hummocks. We feel this is a generally correct assumption, but also could be due to a lack of replicates in the understory and ground components. We observed differences that indicated increased wetness in the reference site such as, higher frequencies of swamp species, a sparse understory, and $T$. distichum knees. This is a minor indication that the absence water management features are allowing for more hydrologic fluxes.

Looking at the forest from a historical perspective, we observe a distinct hydrologic shift to a wetter regime than when agriculture was first abandoned. Figure 2 shows a landscape transformation spanning from cultivation to a bottomland forest over 220 years.

With the aid of aerial photos taken in 1936, 1973, and 2010, we visually examined a modern bottomland hard-

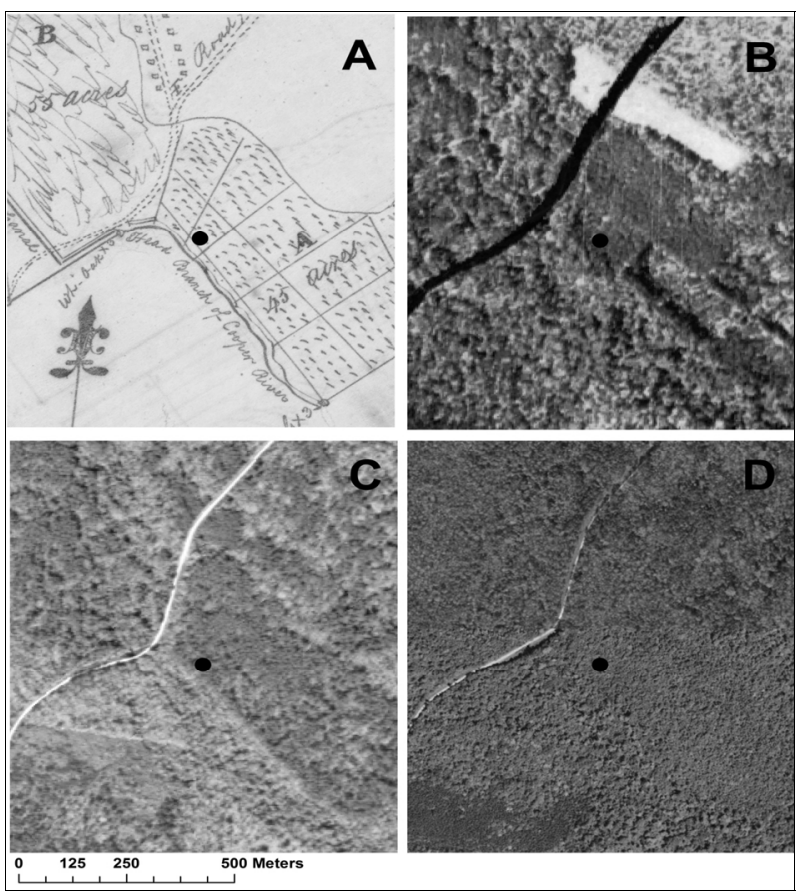

Figure 2. Reforestation since rice cultivation in a non-tidal riparian rice field, A. Plat of Windsor Plantation, 1790, B. 1936 Aerial photo, C. 1973 Aerial photo 1973 and D. 2010 imagery. 
wood stand described as an 8-year-old P. taeda stand in 1905, a 30-year-old stand in 1928, and a saw-timber research plot in 1945 [24-27]. When this old field was sampled, no standing pines were observed, only stumpage from hurricane damage remained. This transformation has been due to the continual erosion of embankments, and it is probable that with continued time deep swamp species may return as the landscape becomes more fluid.

Although it is not the intent of this paper to detail forest regeneration after hurricane damage, we feel it is necessary to demonstrate the resiliency of these bottomland systems. In September1989, Hurricane Hugo caused catastrophic damage to the overstory in the SEF and the surrounding Francis Marion National Forest. Nearly 80\% of the canopy trees were severely damaged or destroyed within the forest [15]. P. taeda had extensive top and stem breakage, and were often uprooted. The bottomlands experienced similar damage, but it was noted that some large crowned oaks lost little foliage in the wind. Two reports were compiled on natural areas within the Francis Marion National Forest [28,29]. A former rice field was inventoried at Poplar Dam, representing a near climax, bottomland hardwood stand reforested from cultivation over 100 years prior. It was described as a beech dominated - southern mixed hardwood forest [28]. Recorded overstory species included Fagus grandifolia, Cornus florida, Ilex opaca, Quercus falcata var. pagodaefolia, Pinus taeda, Pinus glabra, and Cercis canadensis. The report described the presence of many large diameter P. taeda. When the site was inventoried again in 1995, after Hurricane Hugo, the forest stand had been leveled [29]. During our field survey, we observed many small diameter overstory species at the Poplar Dam old-field site. The overstory was dominated by small diameter Ulmus sp., A. rubrum, and Q. laurifolia. F. grandifolia existed as saplings, and $P$. taeda was not observed in any strata.

\section{Conclusion}

Secondary succession occurs quickly, and the old rice fields within the SEF have regenerated through episodes of disturbance to resemble flatwoods and bottomland hardwood stands typical of both soil type and landscape position. The SEF could represent a reference system that has shown a dynamic recovery after major alteration through natural succession, and provides an understanding of the functional capacity of these forested wetlands. While bottomland forests exhibit resilience in regenerating back to a steady state vegetative community, the absence of deep swamp species, Nyssa aquatica and Taxodium distichum in the abandoned rice fields suggest that it may be an effect of the altered hydrology from these water management structures constructed over two hundred years ago. Implicit in these findings is the resilient nature of the riparian zones in the lower coastal plain. Despite decades of cultivation, these sites remain capable of supporting forest communities that are characteristic of the area, but whether the old-fields exhibit differences in productivity or nutrient cycling remains to be determined.

\section{Acknowledgements}

We would like to thank Dr. James B. Edwards for access to Limerick Plantation, Dr. Bo Song, Clemson University for helpful comments on the manuscript, and Ben Collins, Clemson Univ., for help with the field measurements.

\section{REFERENCES}

[1] S. F. Thrush, J. E. Hewitt, P. K. Drayton, G. Coco, A. M. Lohrer, A. Norkko, J. Norkko and M. Chiantore, "Forecasting the Limits of Resilience: Integrating Empirical Research with Theory," Proceedings of the Royal Society, Vol. 276, No. 1671, 2009, pp. 3209-3217.

doi:10.1098/rspb.2009.0661

[2] C. C. Trettin, D. M. Amatya, C. Kaufman, N. Levine and R. T. Morgan, "Recognizing Change in Hydrologic Functions and Pathways Due to Historical Agricultural Use-Implications to Hydrologic Assessments and Modeling," In: R. M. T. Webb and D. J. Semmens, Eds., Planning for an Uncertain Future-Monitoring, Integration, and Adaptation. Proceedings of the Third Interagency Conference on Research in the Watersheds, US Geological Survey Scientific Investigations Report 20095049, 2009, pp. 273-277.

[3] H. R. Smith, "In Land of Cypress and Pine: An Environmental History of the Santee Experimental Forest, 1683-1937," General Technical Report SRS-155, US Department of Agriculture, Forest Service, 2012, p. 17.

[4] N. R. Hawley, "The Old Rice Plantations in and Around the Santee Experimental Forest," Agricultural History, Vol. 23, No. 2, 1949, pp. 86-91.

[5] W. B. Lees, "Limerick Old and in the Way: Archeological Investigations at Limerick Plantation," Anthropological Studies 5, Occasional Papers of the Institute of Archeology and Anthropology, University of South Carolina, Columbia, 1980, p. 205.

[6] W. B. Lees, "The Historical Development of Limerick Plantation, A Tidewater Rice Plantation in Berkeley County, South Carolina, 1683-1945," The South Carolina Historical Magazine, Vol. 82, No. 1, 1981, pp. 44-62.

[7] C. S. Chapman, "A Working Plan for Forest Lands in Berkeley County, South Carolina," United States Department of Agriculture, Bureau of Forestry, Bulletin 56, Washington, 1905, p. 62.

[8] W. H. Conner, J. W. Day, Jr. and W. R. Slater, "Bottomland Hardwood Productivity: A Case Study in a Rapidly Subsiding Louisiana, USA, Watershed," Wetlands Ecology and Management, Vol. 2, No. 4, 1993, pp. 189-197. 


\section{doi:10.1007/BF00188153}

[9] C. H. Wharton, W. M. Kitchens and T.W. Snipe, "The Ecology of Bottomland Hardwood Swamps of the Southeast: A Community Profile," US Fish and Wildlife Service, Biological Services Program, FWS/OBS-81/37, Washington, 1982, p. 133.

[10] D. R. Spencer, J. E. Perry and G. M. Silberhorn, "Early Secondary Succession in Bottomland Hardwood Forests of Southeastern Virginia," Environmental Management, Vol. 27, No. 4, 2001, pp. 559-570. doi: $10.1007 / \mathrm{s} 002670010170$

[11] L. L. Battaglia, P. Minchin and D. W. Pritchett, "Sixteen Years of Old-Field Succession and Re-Establishment of a Bottomland Hardwood Forest in the Lower Mississippi Alluvial Valley," WETLANDS, Vol. 22, No. 1, 2002, pp. $1-17$. doi:10.1672/0277-5212(2002)022[0001:SYOOFS]2.0.CO ;2

[12] L. L. Battaglia, J. R. Keough and D. W. Pritchett, "Early Secondary Succession in a Southeastern US Alluvial Floodplain," Journal of Vegetation Science, Vol. 6, No. 6, 1995, pp. 769-776. doi: $10.2307 / 3236390$

[13] R. Stalter and J. Baden, "A Twenty Year Comparison of Vegetation of Three Abandoned Rice Fields, Georgetown County, South Carolina," Castenea, Vol. 59, No. 1, 1994, pp. 69-77.

[14] D. Gielstra, C. Runyon and J. D. Waldron, "Hydrochory and Successional Changes in Abandoned Rice Fields, Georgetown County, South Carolina," Southeastern Geographer, Vol. 47, No. 2, 2007, pp. 239-253. doi:10.1353/sgo.2007.0024

[15] D. D. Hook, M. A. Buford and T. M. Williams, "Impact of Hurricane Hugo on the South Carolina Coastal Plain Forest," Journal of Coastal Research, Vol. SI8, No. S8, 1991, pp. 291-300.

[16] W. R. Harms, W. M. Aust and J. A. Burger, "Wet Flatwoods," In: M. G. Messina and W. H. Conner, Eds., South Forested Wetlands: Ecology and Management, CRC Press, Boca Raton, 1998, pp. 421-444.

[17] Natural Resource Conservation Service, "Meggett Series, Official Series Description," National Cooperative Soil Survey, United States Department of Agriculture, 2005. http://www2.ftw.nrcs.usda.gov/osd/dat/M/MEGGETT.ht $\mathrm{ml}$
[18] S. V. Harder, D. M. Amatya, T. J. Callahan, C. C. Trettin and J. Hakkila, "Hydrology and Water Budget for a Forested Atlantic Coastal Plain Watershed, South Carolina," JAWRA, Vol. 43, No. 3, 2007, pp. 565-575.

[19] J. Purcell, "A Plan Exhibiting the Shape and Form of a Body of Land Called Limerick," South Caroliniana Library, University of South Carolina, Columbia, 1786.

[20] J. Hardwick, "A Plan of Limerick, A Plantation Belonging to Elias Ball, Esquire," Microfilm, South Carolina Archives, Columbia, 1797.

[21] T. Greene, "Winsdor Plantation [Plat]," Charleston County Register Mesne Conveyance, Charleston, 1790, p. 199.

[22] R. K. Peet, T. R. Wentworth and P. S. White, "A Flexible, Multipurpose Method for Recording Vegetation Composition and Structure," Castanea, Vol. 63, No. 3, 1998, pp. 262-274.

[23] K. M. Flynn and M. Vellend, "Recovery of Forest Plant Communities in Post-Agricultural Landscapes," Frontiers in Ecology and the Environment, Vol. 3, No. 5, 2005, pp. 243-250. doi:10.1890/1540-9295(2005)003[0243:ROFPCI]2.0.CO; $\underline{2}$

[24] United States Department of Agriculture Forest Service, Aerial Photos: 1936, 1941, 1953, 1967, 1973, 1991, 2006, Archives, USDA Forest Service, Santee Experimental Forest, Cordesville, South Carolina.

[25] A. B. Recknagel, "Remeasuring the Hell Hole Plots in South Carolina," Journal of Forestry, Vol. 26, No. 6, 1928, pp. 823-824.

[26] A. L. MacKinney and L. Beasley, "Cruise Notes \& Tally Sheets for Reconnaissance Survey of Proposed Experimental Forest. Wambaw Purchase Unit: Limerick Tract," Unpublished Report, USDA Forest Service, Witherbee, 1934.

[27] T. Lotti, "A Special Fire Plan for the Santee Experimental Forest," USDA Forest Service, Southeastern Forest Experiment Station, Asheville, 1945, p. 26.

[28] R. D. Porcher, "Inventory of Natural Areas in the Francis Marion National Forest," Final Report, USDA Forest Service, Regional Office, Atlanta, 1982, pp. 49-64.

[29] R. D. Porcher, "Inventory of Botanical Natural Areas in Berkeley, Charleston, and Dorchester Counties," Report of Charleston Harbor Project, Charleston, 1995. 